\title{
ARAH CAMPUR TANGAN URUSAN PERADILAN PASAL 3 AYAT (2) UU No. 48 TAHUN 2009 TENTANG KEKUASAAN KEHAKIMAN SEBAGAI KEBIJAKAN HUKUM PIDANA
}

\author{
Ibnu Subarkah, I Nyoman Nurjaya, Bambang Sugiri, Masruchin Ruba’i \\ Fakultas Hukum Universitas Brawijaya, Malang \\ ibnusubarkah65@gmail.com
}

\begin{abstract}
Abstrak
Penelitian ini dilatarbelakangi ketidakjelasan makna larangan campur tangan urusan peradilan dalam Pasal 3 ayat (2) UU No. 48 Tahun 2009 tentang Kekuasaan Kehakiman yang berimplikasi pada arah makna tersebut, dimana dalam prakteknya telah banyak kasus-kasus dalam tingkat ketatanegaraan dan peradilan yang nota bene dapat diselaraskan dengan contempt ofccourt/CoC. yang mempengaruhi kewibawaan hakim dan badan peradilan. Metode yang digunakan melalui penelitian hukum bahan-bahan hukum, dengan analisis preskriptif. Tujuannya adalah untuk mengetahui dan menganalisis hubungan campur tangan dalam Pasal 3 ayat (2) UU No. 48 Tahun 2009 tentang Kekuasaan Kehakiman berkaitan dengan contempt of court, dan diperlukannya kebijakan hukum pidana ke depan.Adapun hasil dan pembahasan ditemukan bahwa antara makna campur tangan urusan peradilan pada Pasal 3 ayat (2) undang-undang di atas hakekatnya tidak berbeda dengan perbuatan penghinaan pengadilan (contempt of court) dimana terdapat sebagian masyarakat yang memandang hal tersebut berbeda, misalnya adanya upaya untuk menyusun pengaturannya melalui RUU CoC dan perubahan KUHP yang mengatur Tindak Pidana dalam Penyelenggaraan Peradilan. Kebijakan hukum pidana yang mengadopsi hukum sebagai satu kesatuan sistem sangat kompeten dalam mengatur implikasi atas norma Pasal 3 ayat (3) undang-undang di atas dengan cara mengusulkan perubahan undang-undang tersebut sebagai hukum pidana khusus ke depan. Kesimpulannya bahwa terdapat hubungan antara Pasal 3 ayat (2) UU No. 48 Tahun 2009 tentang Kekuasaan Kehakiman dengan perbuatan penghinaan pengadilan untuk menentukan arah perubahan UU No. 48 Tahun 2009 tentang Kekuasan Kehakiman melalui Pasal 3 ayat (2) UU tersebut yang hasilnya sebagai kebijakan hukum pidana (hukum pidana khusus).
\end{abstract}

Kata Kunci : Campur Tangan; Contempt of Court; Larangan; Kebijakan Hukum Pidana

\section{DIRECTIONS OF METERING IN JUDICIAL AFFAIRS CHAPTER 3 SECTION (2) OF LAW NO. 48 OF 2009 CONCERNING ABOUT JUDICIAL POWER AS A CRIMINAL LAW POLICY}

\begin{abstract}
This research is backgrounded by the unclear meaning of the prohibition against intervention in judicial affairs in Article 3 paragraph (2) of Law no. 48 of 2009 concerning Judicial Power which has implications for the direction of this meaning, where in practice there have been many cases at the state and judicial level which can be harmonized with the contempt of court/CoC. which affects the authority of judges and judicial bodies. The method used is through legal research on legal materials, with prescriptive analysis. The aim is to find out and analyze the relationship between intervention in Article 3 paragraph (2) of Law No., 48 of 2009 concerning Judicial Power relating to the Contempt of Court, and the need for criminal law policies in the future. The results and discussion found that between the meaning of intervention Judicial affairs in Article 3 paragraph (2) of the law above are essentially no different from Contempt of Court, where there are some people who view it differently, for example, there are efforts to compile the regulation through the $\mathrm{CoC}$ Bill and amendments to the Criminal Code which regulates Crime in the Administration of Justice. The criminal law policy that adopts the law as a unified system is very competent in regulating the implications of the norms of Article 3 paragraph (3) of the above law by proposing changes to the law as a special criminal law in the future. The conclusion is that there is a relationship between Article 3 paragraph (2) of Law no. 48 of 2009 concerning Judicial Power with contempt of court to determine the direction of changes to Law no. 48 of 2009 concerning Judicial Power through Article 3 paragraph (2) of the Law which results as a criminal law policy (special criminal law).
\end{abstract}

Keywords: Intervention; Contempt of Court; Prohibition; Criminal Law Policy 


\section{A. PENDAHULUAN}

Negara Indonesia adalah negara hukum, suatu negara berdasarkan hukum. ${ }^{1}$ Negara hukum tersebut, dalam Kekuasaan Kehakiman, mempunyai adanya Kekuasaan kehakiman yang merdeka, Kemandirian peradilan dan Kebebasan Hakim. Kekuasaan Kehakiman yang bebas dari campur tangan pihak manapun. Pasal 24 ayat (1) Undangundang Dasar Negara Republik Indonesia Tahun 1945 yang disingkat UUD NRI Tahun 1945 telah menyebutkan "kekuasaan kehakiman merupakan kekuasaan yang merdeka untuk menyelenggarakan peradilan guna menegakkan hukum dan keadilan."2

Secara historis, dalam upaya perlindungan terhadap kekuasaan kehakiman ini telah diatur dalam peraturan perundang-undangan dengan berbagai perubahan. Hanya saja substansi/isi tidak jauh berbeda, atau mengalami perubahan yang signifikan, Hal ini dikarenakan adanya pemikiran-pemikiran dalam menyusun sistem pemerintahan di Indonesia yang berlandaskan pada konstitusi dan perundang-undangan, dimana negara hukum dalam bentuknya rechtstaat, dengan sistem hukum yang masih dipengaruhi oleh civil law system, bahwa legalitas dalam segala bentuknya merupakan suatu upaya menjamin keberlangsungan hak-hak asasi manusia, termasuk hak asasi manusia dalam bidang peradilan.

Pada Undang-undang No. 48 Tahun 2009 tentang Kekuasaan Kehakiman, disebut dengan frase "cukup jelas", dalam menjelaskan Pasal 3 ayat (3). Selanjutnya bunyi lengkap Pasal 3 UU No. 48 Tahun 2009 tentang Kekuasaan Kehakiman sebagai berikut:

(1) Dalam menjalankan tugas dan fungsinya, hakim dan hakim konstitusi wajib menjaga kemandirian peradilan.

(2) Segala campur tangan dalam urusan peradilan oleh pihak lain di luar kekuasaan kehakiman dilarang, kecuali dalam hal-hal sebagaimana dimaksud dalam Undang-undang Dasar Negara Republik Indonesia Tahun 1945.

(3) Setiap orang yang dengan sengaja melanggar ketentuan sebagaimana dimaksud pada ayat (2) dipidana sesuai dengan ketentuan peraturan perundang-undangan. ${ }^{3}$

Larangan sebagaimana yang ditentukan pada Pasal 3 ayat (2) Undang-undang tentang Kekuasaan Kehakiman mempunyai sanksi pidana. Hukum pidana mengisyaratkan adanya perbuatan pidana, pertanggungjawaban pidana dan hukum prosedur. Hukum pidana menempatkan hanya manusia dan badan hukum/korporasi dapat dipidana. Korporasi menurut hukum pidana Indonesia tidak sama dengan pengertian korporasi dalam hukum perdata. Pengertian korporasi menurut hukum pidana lebih luas daripada pengertian menurut hukum perdata. ${ }^{4}$ Manusia/badan hukum dalam posisi, bisa sebagai pelaku, atau korban. Berkaitan dengan Pelaku Kekuasaan Kehakiman, Pasal 18 dan 19 Undang-undang No. 48 Tahun 2009 tentang Kekuasaan Kehakiman, Bab III,

\footnotetext{
${ }^{1}$ Majelis Permusyawaratan Rakyat Republik Indonesia,, Panduan Pemasyarakatan Undang-Undang Dasar NRI Tahun 1945 sesuai dengan urutan Bab, Pasal, dan Ayat, Cet. Ke 3, Sekjend MPR RI, 2007, Pasal 1 ayat (3) UUD NRI Tahun 1945

${ }^{2}$ Ibid

${ }^{3}$ Undang-undang Nomor 48 Tahun 2009 Tentang Kekuasaan Kehakiman.

4 Rizqi Purnama Puteri, Muhammad Junaidi, Zaenal Arifin, "Reorientasi Sanksi Pidana Dalam Pertanggungjawaban Korporasi Di Indonesia", Jurnal USM Law Review 3, no. 1 (2020): 98-111, http://dx.doi.org/10.26623/julr.v3i1.2283
} 
Bagian Kesatu Umum telah menyebutkan Badan/institusi/lembaga, hakim dan hakim konstitusi. ${ }^{5}$

Penelitian ini merupakan berhubungan langsung dengan penelitian sebelumnya oleh Subarkah (2015). Penelitian ini mengkaji bentuk-bentuk campur tangan urusan peradilan di luar kekuasaan kehakiman berdasar Pasal 3 Undang-undang No. 48 Tahun 2009 tentang kekuasaan kehakiman, dan penanggulangannya. Hasil penelitian menunjukkan bahwa bentuk-bentuk campur tangan secara praktis menurut beberapa hakim dalam wilayah Pengadilan Tinggi Jawa Timur, yaitu hakim Pengadilan Negeri Kabupaten Malang, Kota Malang, dan Jaksa Kabupaten Malang pengaruh mempengaruhi terhadap putusan hakim, jalannya persidangan dan segera dilaksanakan penahanan dilakukan melalui penyuapan, gratifikasi, dan pengaruh pemberitaan terhadap jalannya pemeriksaan. ${ }^{6}$

Penelitian oleh Adonara (2016) juga terkait dengan penelitian ini. Penelitian oleh Adonara mangakagkat permasalahan tentang makna dan fungsi prinsip kebebasan hakim dalam memutuskan suatu perkara yang ditanganinya dan bagaimana implementasi prinsip kebebasan hakim dalam memutuskan suatu perkara yang ditanganinya. Hasil dari penelitian tersebut adalah "prinsip kebebasan hakim dalam menjalankan tugasnya sebagai hakim, dapat dimaknai bahwa hakim dalam menjalankan tugas kekuasaan kehakiman tidak boleh terikat dengan apa pun dan/ atau tertekan oleh siapa pun, tetapi leluasa untuk berbuat apa pun”. Sedangkan implementasi prinsip kebebasan hakim dalam memutuskan suatu perkara yang ditanganinya hakim harus bebas dari campur tangan di luar kekuasaan kehakiman baik itu dari eksekutif, legislatif masyarakat maupun pers. ${ }^{7}$

Sedangkan penelitian selanjutnya oleh Suherman (2019) mengkaji tentang problematika independensi hakim sebagai pelaksana kekuasaan kehakiman, dan merupakan instrumentarium hukum bagi hakim dalam melaksanakan fungsinya mengadili dan memutus suatu perkara yang dihadapkan kepadanya agar terbebas dari segala interfensi dan atau pengaruh dari lingkungan kekuasaan lainnya baik itu dari lingkungan organ kekuasaan eksekutif maupun dari lingkungan organ kekuasaan legislatif. Hasil penelitian ini mengemukakan bahwa hakim dalam memutus perkara di Indonesia masih eksis menggali dan menemukan rasa keadilan ditengah masyarakat, bahkan dengan pendekatan norma agama dimana diketahui masyarakat Indonesia cukup patuh terhadap norma agama. ${ }^{8}$

5 Ibid, Pasal 18 UU No. 48 Tahun 2009 tentang Kekuasaan Kehakiman disebutkan bahwa Kekuasaan kehakiman dilakukan oleh sebuah Mahkamah Agung dan badan peradilan yang berada di bawahnya dalam lingkungan peradilan umum, lingkungan peradilan agama, lingkungan peradilan militer, lingkungan peradilan tata usaha negara, dan oleh sebuah Mahkamah Konstitusi. Selanjutnya disebut sebagai pelaku kekuasaan kehakiman; Sedangkan dalam Pasal 19 menyebutkan bahwa hakim dan hakim konstitusi adalah pejabat negara yang melakukan kekuasaan kehakiman yang diatur dalam undang undang."

${ }^{6}$ Ibnu Subarkah, Lukman Hakim, "Penanggulangan Campur Tangan Urusan Peradilan Di Luar Kekuasaan Kehakiman Berbasis Penal Reform". Yustisia 4 no. 2 (2015) https://doi.org/10.20961/yustisia.v4i2.8650

${ }^{7}$ Firman Floranta Adonara,"Prinsip Kebebasan Hakim dalam Memutus Perkara Sebagai Amanat Konstitusi", Jurnal Konstitusi 12 no. 2 (2015) http://dx.doi.org/10.31078/jk1222

8 Andi Suherman, "Implementasi Independensi Hakim Dalam Pelaksanaan Kekuasaan Kehakiman", SIGn Jurnal Hukum 1 no. 1 (2019) https://doi.org/10.37276/sjh.v1i1.29 
Perbedaan penelitian ini dengan penelitian sebelumnya yaitu bahwa penelitian ini dilatar belakangi oleh tidak jelasnya Pasal 3 Undang-undang No. 48 Tahun 2009 tentang Kekuasaan Kehakiman yang berkaitan dengan penerapan hukum pidana yang mengedepankan fungsi melarang (verbeiten), yang sebaliknya tidak sama sekali mengatur yang diperintahkan, yang dibolehkan dan yang seharusnya berdasarkan nilai-nilai etika, estetika, metafisika, dan logika. Berbeda dengan penelitian oleh Adonara dan Suherman yang mengangkat tentang independensi hakim dalam memutus suatu perkara yang harus lepas dari pengaruh di luar kekuasaan kehakiman. Tujuan penelitin ini adalah untuk mengetahui dan menganalisis hubungan campur tangan dalam Pasal 3 ayat (2) UU No. 48 Tahun 2009 tentang Kekuasaan Kehakiman berkaitan dengan contempt of court, dan diperlukannya kebijakan hukum pidana ke depan.

\section{B. PERMASALAHAN}

Berdasar latar belakang di atas, titik berat permasalahannya untuk memaknai larangan, yang mempunyai implikasi adanya sanksi pidana atau pemidanaan terhadap para pihak yang terlibat sengketa pada badan peradilan, maka dapat dirumuskan permasalahan yaitu apakah perbuatan campur tangan urusan peradilan Pasal 3 ayat (2) UU No. 48 Tahun 2009 tentang Kekuasaan Kehakiman memiliki hubungan dengan contempt of court? dan bagaimakah Kebijakan hukum pidana UU No. 48 Tahun 2009 tentang Kekuasaan Kehakiman ke depan?

\section{METODE PENELITIAN}

Penelitian ini merupakan penelitian hukum, dengan bahan hukum primer Pasal 3 ayat (2) Undang-undang No. 48 Tahun 2009 tentang Kekuasaan Kehakiman, yang didukung bahan hukum sekunder berupa referensi-referensi pustaka, ilustrasi kasus yang berkaitan dengan adanya perbuatan dengan kualifikasi campur tangan urusan peradilan. Analisis bahan hukum menggunakan analisis preskriptif.

\section{HASIL DAN PEMBAHASAN}

\section{Hubungan Campur Tangan Urusan Peradilan Pasal 3 ayat (2) UU No. 48 Tahun 2009 Tentang Kekuasaan Kehakiman dengan Contempt of Court .}

Suatu sistem hukum yang modern harus dapat membentuk hukum yang baik, yang mencerminkan rasa keadilan bagi semua pihak dan sesuai dengan kondisi masyarakat. Hukum dibuat sesuai dengan prosedur yang telah ditentukan, dan juga harus dimengerti atau dipahami oleh masyarakat secara keseluruhan. ${ }^{9}$

Perwujudan negara hukum dalam konstitusi menggariskan bahwa kekuasaan kehakiman merupakan kekuasaan yang merdeka. Hal itu secara jelas diatur pada Pasal 24 Ayat (1) UUD 1945 yang menegaskan bahwa "kekuasaan kehakiman merupakan kekuasaan yang merdeka untuk menyelenggarakan peradilan guna menegakkan hukum dan keadilan”. Dengan demikian, independensi kekuasaan kehakiman merupakan prasyarat utama agar dapat ditegakkannya hukum dan keadilan. ${ }^{10}$

\footnotetext{
${ }^{9}$ Arif Hidayat, Zaenal Arifin, "Politik Hukum Legislasi Sebagai Socio-Equilibrium Di Indonesia”, Jurnal Ius Constituendum 4 no. 2 (2019) http://dx.doi.org/10.26623/jic.v4i2.1654

10 Muh. Ridha Hakim, "Tafsir Independensi Kekuasaan Kehakiman Dalam Putusan Mahkamah Konstitusi”, Jurnal Hukum dan Peradilan 7, no. 2 (2018): 279 - 296, http://doi.org/10.25216/jhp.7.2.2018.279-296
} 
Kekuasaan kehakiman dalam susunan kekuasaan negara menurut Perubahan Undang-Undang Dasar Negara Republik Indonesia Tahun 1945 tetap ditempatkan pada kekuasaan yang mandiri bebas dari campur tangan kekuasaan lain. Dalam susunan kekuasaan negara setelah Perubahan Undang-undang Dasar Negara Republik Indonesia Tahun 1945, kekuasaan kehakiman dilakukan oleh sebuah Mahkamah Agung dan badan peradilan yang berada di bawahnya dalam lingkungan peradilan umum, lingkungan peradilan agama, lingkungan peradilan militer, lingkungan peradilan tata usaha negara, dan oleh sebuah Mahkamah Konstitusi. ${ }^{11}$

Campur tangan mempunyai makna sesungguhnya sebagai pihak ke 3 yang ikut perselisihan 2 (dua) pihak lainnya. ${ }^{12}$ Kata tersebut selalu melekat atau dapat dikatakan sebagai bahasa hukum perundang-undangan. Pokok persoalannya adalah kata tersebut mempunyai implikasi hukum terjadinya polemik yang berkepanjangan, penelitian ini menyampaikan implikasi dalam praktek ketatanegaraan dan dalam praktek peradilan. Perubahan undang-undang sekaligus pembahasannya oleh pemerintah bersama DPR lebih tertuju pada praktik penyelenggaraan sistem pemerintahan.

Istilah contempt of court dapat ditemukan pada penjelasan umum butir ke empat alinea ke empat Undang-undang Nomor 14 tahun 1985 tentang Mahkamah Agung yang menyebutkan "bahwa selanjutnya untuk dapat lebih menjamin terciptanya suasana yang sebaik-baiknya bagi penyelenggaraan peradilan guna menegakkan hukum dan keadilan yang mengatur penindakan terhadap perbuatan, tingkah laku, sikap dan/atau ucapan yang dapat merendahkan dan merongrong kewibawaan, martabat, dan kehormatan badan peradilan yang dikenal sebagai contempt of court". ${ }^{13}$

Sebagai suatu alasan pembenar, bahwa dalam praktek ketatanegaraan dengan gencar dan sporadis melakukan beberapa kali perubahan agar kekuasaan kehakiman bebas dari campur tangan kekuasaan lainnya. Political will pemerintah, DPR dan masyarakat selalu mengkaitkan dengan konsep negara hukum yang dicita-citakan agar kekuasaan yudikatif tidak dicampuri oleh kekuasaan eksekutif, legislatif merubah sekaligus menetapkan perundang-undangan di bidang peradilan dimana pisau analisisnya menggunakan teori pemisahan kekuasaan dimana kebebasan dan hak warga negara mendapat perlindungan. Makna kebebasan tersebut dalam kaitan dengan teori pemisahan kekuasaan menurut Aidul Fitriciada Azhari, ${ }^{14}$ merupakan "Tujuan pemisahan kekuasaan (separation of power/séparation des pouvoirs/ scheiding van machten) berasal dari pemikiran Charles de Secondat, Baron de Montesquieu dalam karyanya De l'esprit des lois."

${ }^{11}$ Achmad Edi Subiyanto, "Mendesain Kewenangan Kekuasaan Kehakiman Setelah Perubahan UUD 1945", Jurnal Konstitusi 9 no. 4 (2012) http://dx.doi.org/10.31078/jk\%x

12 https://www.kamusbesar.com/campur-tangan, turut mencampuri (memasuki) perkara orang lain; (arti; tersangkut atau terlibat dl suatu tindakan kejahatan (perkara orang lain dsb); (arti), diakses 5 Oktober 2021, pukul 12.06 WIB.

${ }^{13}$ Syarif Nurhidayat, "Pengaturan Dan Ruang Lingkup Contempt Of Court Di Indonesia”, Jurnal Ius Constituendum 6 no. 1 (2021) http://dx.doi.org/10.26623/jic.v6i1.2419

14 Aidul Fitriciada Azhari, Paradigma Kekuasaan Kehakiman Sebelum dan Sesudah Reformasi dalam Meluruskan Arah Manajemen Kekuasaan Kehakiman, Jakarta: Sekretaris Jenderal Komisi Yudisial Republik Indonesia, (2018). 
Pada Gambar 1 di bawah ini telah dijelaskan adanya dampak-dampak dari sebuah kata campur tangan.

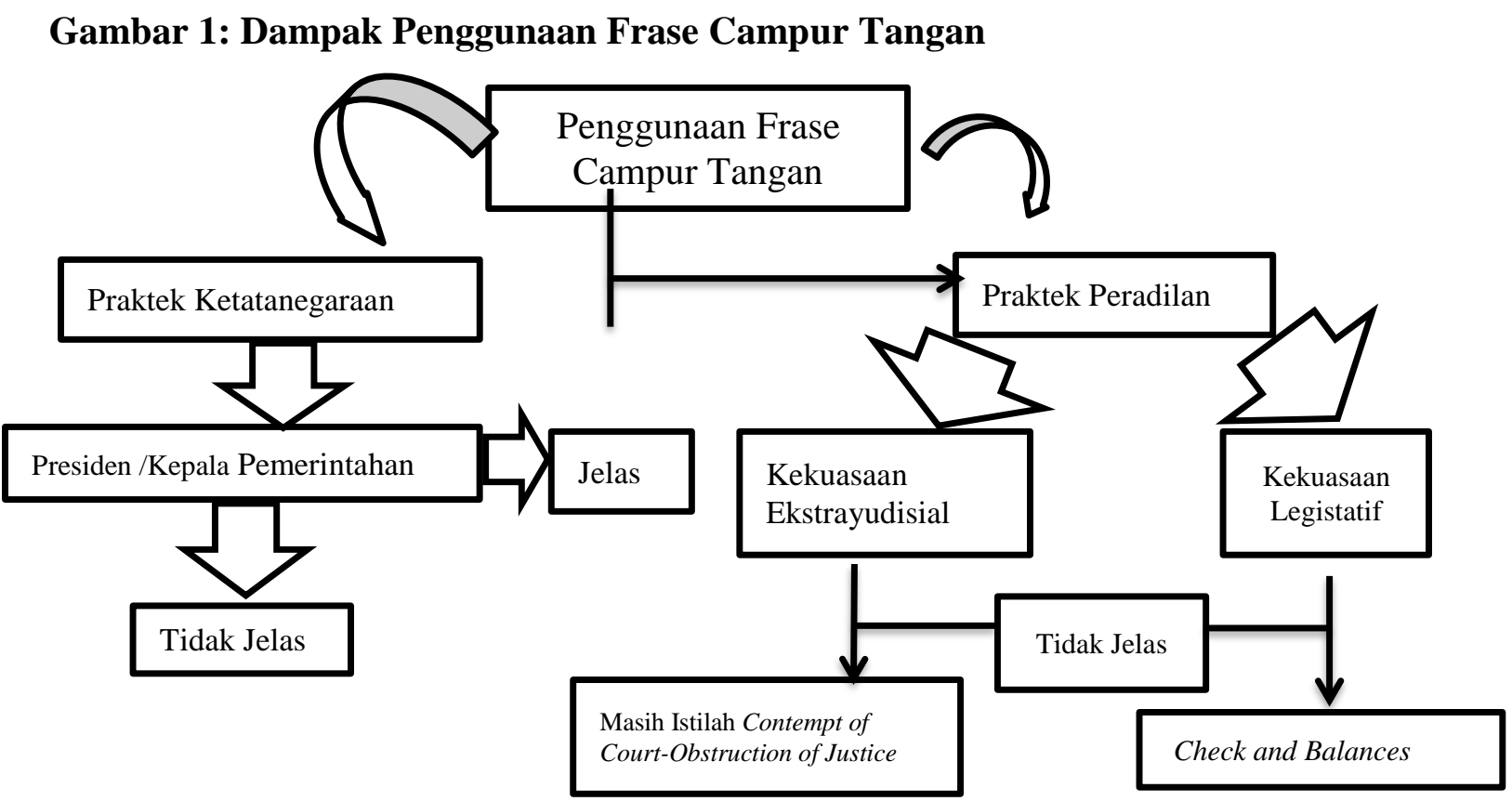

Salah satu elemen yang terkandung dalam konsepsi negara hukum rechtsstaat adalah adanya pemisahan kekuasaan, artinya bilamana dihubungan dengan konsep Trias Politica, terdapat pemisahan yang tegas antara cabang-cabang kekuasaan eksekutif, legislatif, dan yudikatif. Pemisahan ini bertujuan agar kekuasaan tidak terkonsentrasi hanya pada satu organ serta untuk membatasi tiap-tiap cabang kekuasaan agar tidak terjadi abuse of power. ${ }^{15}$

Montesquieu menegaskan bahwa "penyatuan kekuasaan legislatif dan eksekutif pada satu orang atau satu lembaga akan melahirkan tirani kekuasaan yang mengakibatkan hilangnya kebebasan. Hal yang sama berlaku pula dengan kekuasaan kehakiman."16

Negara Indonesia sejak orde lama berakhir, pada tahun 1970 telah memperbaika sistem pemerintahan yang ada agar dapat memberikan perlindungan terhadap kekuasaan kehakiman yang merdeka, peradilan dijalankan secara mandiri, yang berimbas pada kebebasan hakim. Tabel 1 di bawah ini menunjukkan bagaimana alasan-alasan perubahan yang tertera dalam pertimbangan hukum masing-masing perundang-undangan.

15 Aditya Wiguna Sanjaya, "Celah Intervensi Kekuasaan Eksekutif Terhadap Kekuasaan Yudikatif Di Lingkungan Peradilan Militer”, Jurnal Panorama Hukum 3, no. 2 (2018): 206, https://doi.org/10.21067/jph.v3i2.2823 ${ }^{16}$ Azhari 
Tabel 1.

Diskripsi Pertimbangan, Norma, Penjelasan Adanya Perundang-Undangan Kekuasaan Kehakiman.

\begin{tabular}{|c|c|c|c|c|}
\hline No & $\begin{array}{l}\text { Perundang- } \\
\text { Undangan }\end{array}$ & $\begin{array}{l}\text { Pertimbangan } \\
\text { Adanya Undang- } \\
\text { Undang }\end{array}$ & Penjelasan & Keterangan \\
\hline 1. & $\begin{array}{l}\text { UU No. } 14 \text { Tahun } \\
1970 \text { tentang } \\
\text { Ketentuan- } \\
\text { ketentuan Pokok } \\
\text { Kekuasaan } \\
\text { Kehakiman } \\
\text { (Lembaran } \\
\text { Negara Republik } \\
\text { Indonesia Tahun } \\
1970 \text { Nomor 74, } \\
\text { Tambahan } \\
\text { Lembaran Negara } \\
\text { Nomor 2951) }\end{array}$ & $\begin{array}{l}\text { a. bahwa Undang- } \\
\text { undang No. } 19 \text { tahun } \\
1964 \text { tentang } \\
\text { Ketentuan ketentuan } \\
\text { Pokok Kekuasaan } \\
\text { Kehakiman } \\
\text { (Lembaran-Negara } \\
\text { tahun1964 No. 107) } \\
\text { tidak merupakan } \\
\text { pelaksanaan murni } \\
\text { dan pasal } 24 \\
\text { Undang-undang Dasar } \\
\text { 1945, karena memuat } \\
\text { ketentuan-ketentuan } \\
\text { yang bertentangan } \\
\text { dengan Undang- } \\
\text { undang Dasar 1945, } \\
\text { b. bahwa Undang- } \\
\text { undang No. 19 tahun } \\
\text { 1964 tentang } \\
\text { Ketentuan ketentuan } \\
\text { Pokok Kekuasaan } \\
\text { Kehakiman } \\
\text { (Lembaran-Negara } \\
\text { tahun 1964 No. 107) } \\
\text { telah dinyatakan tidak } \\
\text { berlaku dengan } \\
\text { Undang-undang No. } 6 \\
\text { tahun } 1969 \text { tetapi saat } \\
\text { tidak berlakunya } \\
\text { undang undang } \\
\text { tersebut ditetapkan } \\
\text { pada saat undang- }\end{array}$ & $\begin{array}{l}\text { Bab I Ketentuan } \\
\text { Umum. } \\
\text { Pasal } 4 . \\
\text { (1) Peradilan } \\
\text { dilakukan "DEMI } \\
\text { KEADILAN } \\
\text { BERDASARKA } \\
\text { N KETUHANAN } \\
\text { YANG MAHA } \\
\text { ESA". } \\
\text { (2) Peradilan } \\
\text { dilakukan dengan } \\
\text { sederhana, cepat } \\
\text { dan biaya ringan. } \\
\text { (3) Segala campur } \\
\text { tangan dalam } \\
\text { urusan peradilan } \\
\text { oleh fihak-fihak } \\
\text { lain di luar } \\
\text { kekuasaan } \\
\text { kehakiman } \\
\text { dilarang, kecuali } \\
\text { dalam hal-hal } \\
\text { yangtersebut } \\
\text { dalam Undang- } \\
\text { undang Dasar. }\end{array}$ & $\begin{array}{l}\text { Pasal } 3 \\
\text { Di sini perlu } \\
\text { ditegaskan, } \\
\text { bahwa agar } \\
\text { supaya } \\
\text { pengadilan } \\
\text { dapat } \\
\text { menaikan } \\
\text { tugasnya } \\
\text { dengan } \\
\text { sebaik- } \\
\text { baiknya, } \\
\text { yakni } \\
\text { memberikan } \\
\text { keputusan } \\
\text { yang semata- } \\
\text { mata } \\
\text { berdasarkan } \\
\text { kebenaran, } \\
\text { keadilan dan } \\
\text { kejujuran, } \\
\text { maka tidak } \\
\text { dapat } \\
\text { dibenarkan } \\
\text { adanya } \\
\text { tekanan- } \\
\text { tekanan atau } \\
\text { pengaruh- } \\
\text { pengaruh dari } \\
\text { luar } \text { yang } \\
\text { akan } \\
\text { menyebabkan } \\
\text { para hakim }\end{array}$ \\
\hline
\end{tabular}




undang yang
menggantikannya
mulai berlaku;
c. bahwa berhubung
dengan hal-hal
tersebut diatas perlu
ditetapkan
undang undang baru
mengenai ketentuan-
ketentuan pokok
kekuasaan kehakiman
yang sesuai dengan
Pancasila dan
Undang-
undang Dasar 1945;

undang yang

menggantikannya

mulai berlaku;

c. bahwa berhubung

dengan hal-ha

tersebut diatas perlu

ditetapkan

undang undang baru

ketentuan pokok

kekuasaan kehakiman

yang sesuai dengan

Pancasila dan

undang Dasar 1945;

2. UU No. 35 Tahun

1999 tentang

Perubahan Atas

UU No. 14 Tahun

1970 tentang

Ketentuan-

ketentuan Pokok

Kekuasaan

Kehakiman

(Lembaran

Negara Republik

Indonesia Tahun

1999 Nomor 147) a. bahwa kekuasaan

Kehakiman adalah

kekuasaan yang

merdeka dan oleh

karena itu untuk

mewujudkan

kekuasaan kehakiman

yang mandiri dan

terlepas dari

kekuasaan pemerintah

dipandang perlu

melaksanakan

pemisahan yang tegas tidak bebas

lagi dalam

mengambil

keputusan

yang seadil-

adilnya.

Keterangan:

Telah

diadopsi

sebagai Asas

Kemandirian

Peradilan

(UU No. 48

Tahun 2009

tentang

Kekuasaan

Kehakiman),

akan tetapi

tidak

dijelaskan

bentuk

campur

tangan dan

konsep-

konsep secara

kontektual

ayat (3).

Tidak ada Tidak ada

perubahan sesuai

uu sebelumnya 
antar fungsi yudikatif

dan eksekutif;

3. UU No. 4 Tahun

a. Bahwa kekuasaan

2004 tentang

Kekuasaan

Kehakiman

(Lembaran

Negara Republik

Indonesia Tahun 2004 Nomor 8)

kehakiman menurut

Undang-undang

Dasar Negara

Republik Indonesia

Tahun 1945

yang merdeka yang merupakan kekuasaan

dilakukan oleh

sebuah Mahkamah

Agung dan badan

peradilan di

bawahnya, dan oleh

sebuah Mahkamah

Konstitusi, untuk

menyelenggarakan

peradilan guna

menegakkan hukum

dan keadilan;

b. bahwa perubahan

Undang-undang Dasar

Negara Republik

Indonesia Tahun 1945

telah membawa

perubahan penting

terhadap

penyelenggaraan

kekuasaan kehakiman

sehingga Undang-

undang Nomor 14

Tahun 1970 tentang

Ketentuan-ketentuan

Pokok Kekuasaan

Kehakiman

sebagaimana telah

diubah dengan

Undang-undang

Nomor 35 Tahun 1999
Bab I Ketentuan

Umum

Pasal 4

(1) Peradilan

dilakukan "DEMI

KEADILAN

BERDASARKA

N KETUHANAN

YANG MAHA

ESA".

(2) Peradilan

dilakukan dengan

sederhana, cepat, dan biaya ringan.

(3) Segala campur

tangan dalam

urusan peradilan

oleh pihak lain di

luar kekuasaan

kehakiman

dilarang, kecuali

dalam hal-hal

sebagaimana

disebut dalam

Undang-undang

Dasar Negara

Republik

Indonesia Tahun 1945.

(4) Setiap orang

yang dengan

sengaja

melanggar

ketentuan

sebagaimana

dimaksud pada

ayat (3) dipidana.
Ayat (3)

Cukup jelas.

Ayat (4)

Yang

dimaksud

"dipidana"

dalam ayat ini

adalah bahwa

unsur-unsur

tindak pidana

dan

pidananya

ditentukan

dalam

undang-

undang

Keterangan:

Ada

penjelasan

yang konkrit

pemidanaan

mengacu

pada uu.

Akan tetapi

tidak

dijelaskan

bentuk

campur

tangannya

dan

penjelasan

secara

kontekstual

atas ayat (3)

tersebut. 


$$
\begin{aligned}
& \text { perlu dilakukan } \\
& \text { penyesuaian dengan } \\
& \text { Undang-undang Dasar } \\
& \text { Negara Republik } \\
& \text { Indonesia Tahun } \\
& \text { 1945; }
\end{aligned}
$$

4. UU No. 48 Tahun

a. bahwa kekuasaan 2009 tentang

Kekuasaan

Kehakiman

(Lembaran

Negara Republik Indonesia Tahun 2009, Nomor 157).

Undang-undang Dasar

Negara Republik

Indonesia Tahun 1945

merupakan kekuasaan

yang merdeka yang

dilakukan oleh sebuah

Mahkamah Agung kehakiman menurut

dan badan peradilan

yang berada di

bawahnya dalam

lingkungan peradilan

umum, lingkungan

peradilan agama,

lingkungan peradilan

militer, lingkungan

peradilan tata usaha

negara, dan oleh

sebuah Mahkamah

Konstitusi, untuk

menyelenggarakan

peradilan guna

menegakkan hukum

dan keadilan;

b. bahwa untuk

mewujudkan

kekuasaan kehakiman

yang merdeka dan

peradilan yang bersih

serta berwibawa perlu

dilakukan penataan

sistem peradilan yang

terpadu;
Keterangan: Telah

ada pemidanaan.

Bab II. Asas-asas

Penyelenggaraan

Kekuasaan

Kehakiman

Pasal 3

(1) Dalam

menjalankan

tugas dan

fungsinya, hakim

dan

hakim konstitusi

wajib menjaga

kemandirian

peradilan.

(2) Segala campur

tangan dalam

urusan peradilan

oleh pihak lain di

luar kekuasaan

kehakiman

dilarang, kecuali

dalam hal-hal

sebagaimana

dimaksud dalam

Undang-undang

Dasar Negara

Republik

Indonesia Tahun

1945.

(3) Setiap orang

yang dengan

sengaja

melanggar

ketentuan
Pasal 3

Ayat (1)

Yang

dimaksud

dengan

"kemandirian

peradilan"

adalah bebas

dari campur

tangan pihak

luar dan

bebas dari

segala bentuk

tekanan,baik

fisik maupun

psikis.

Ayat (2)

Cukup jelas.

Ayat (3)

Cukup jelas.

Keterangan:

Kemandirian

peradilan

telah

dikonkritkan

dan sebagai

asas. 


$\begin{array}{ll}\text { c. bahwa Undang- } & \text { sebagaimana } \\ \text { undang Nomor 4 } & \text { dimaksud pada } \\ \text { Tahun 2004 tentang } & \text { ayat (2) dipidana } \\ \text { Kekuasaan } & \text { sesuai dengan } \\ \text { Kehakiman tidak } & \text { ketentuan } \\ \text { sesuai lagi dengan } & \text { peraturan } \\ \text { perkembangan } & \text { perundang- } \\ \text { kebutuhan hukum dan } & \text { undangan. } \\ \text { ketatanegaraan } & \\ \text { menurut Undang- } & \\ \text { undang Dasar Negara } & \\ \text { RepublikIndonesia } & \\ \text { Tahun 1945; } & \end{array}$

Sumber: Bahan Hukum Primer, diolah, 2021

Dari keterangan Tabel 1, dapat dijelaskan bahwa pertimbangan hukum yang termaktub pada huruf c UU No. 48 Tahun 2009 tentang Kekuasaan Kehakiman, menyebutkan bahwa perubahan terhadap UU No. 4 Tahun 2004 tentang Kekuasaan Kehakiman, dengan alasan tidak sesuai dengan kebutuhan hukum dan ketatanegaraan menurut UUD NRI Tahun 1945 dan dilakukan dalam upaya untuk membentuk sistem peradilan yang terpadu. Kekuasaan kehakiman yang merdeka, peradilan yang bersih dan berwibawa, bebas dari campur tangan pihak luar, bebas dari segala tekanan baik fisik maupun psikis.

Dalam praktik hukum, beberapa kalangan antara lain advokat, akademisi, termasuk Ikatan Hakim Indonesia, belum sependapat apabila pengaturan perbuatan campur tangan tersebut dapat diselaraskan dengan perbuatan penghinaan pengadilan (contempt of court). Penelitian ini menyampaikan bahwa pengaturan campur tangan urusan peradilan dalam Pasal 3 ayat (2) Undang-undang Kekuasaan Kehakiman dapat diselaraskan dengan perbuatan contempt of court atau kerap kali disebut dengan tindak pidana dalam penyelenggaraan peradilan. Melalui asas kesamaan, semua pihak yang terlibat dalam perkara di pengadilan memiliki tanggung jawab yang sama terhadap terjadinya penghinaan pengadilan. Oleh karena itu, yang dikatakan dengan pihak lain di luar kekuasaan kehakiman adalah para pihak yang dapat mempengaruhi perselisihan sengketa di pengadilan. Para pihak tersebut berasal dari penegak hukum (polisi, jaksa, hakim), pihak yang memiliki kekuasaan lainnya dari salah satu yang berperkara, pihak atasan penegak hukum (hakim) atau pihak-pihak ektra yudisial.

Campur tangan urusan peradilan sebagai bentuk untuk mengimplementasikan kekuasaan kehakiman yang merdeka mempertegas hakekat urusan peradilan yaitu pada fungsi peradilannya. Mahfud $\mathrm{MD}^{17}$ pernah menyampaikan bahwa "perumusan UUD 1945 tentang penganutan prinsip kemerdekaan kekuasaan kehakiman tidak mencakup

${ }^{17}$ Moh. Mahfud MD, Pergulatan Politik dan Hukum Di Indonesia, Jakarta: Gama Media, (1999). 
pengorganisasian atau hubungan organisatoris antara organisasi kekuasaan yudikatif dan organisasi kekuasaan eksekutif. Yang disebutkan hanyalah prinsip bahwa kekuasaan kehakiman harus bebas dan merdeka dan itu bisa diartikan hanya berlaku bagi fungsi peradilannya".

Berkenaan dengan fungsi peradilan ini adalah sebagai tempat untuk menyelesaikan perselisihan antar 2 (dua) pihak yang berperkara, dapat dikaitkan dengan Penjelasan Umum butir 4 Undang-undang No. 14 Tahun 1985 tentang Mahkamah Agung, bahwa :

"Untuk dapat lebih menjamin terciptanya suasana yang sebaik- baiknya bagi penyelenggaraan peradilan guna menegakkan hukum dan keadilan berdasarkan Pancasila, maka perlu pula dibuat suatu undang- undang yang mengatur penindakan terhadap perbuatan, tingkah laku, sikap dan/atau ucapan yang dapat merendahkan dan merongrong kewibawaan, martabat, dan kehormatan badan peradilan yang dikenal sebagai "contempt of court". ${ }^{18}$

Maka dapat ditegaskan segala campur tangan urusan peradilan Pasal 3 ayat (2) UU No. 48 Tahun 2009 tentang Kekuasaan Kehakiman merupakan penjabaran nilai-nilai abstrak dari asas kemandirian peradilan yaitu bebas campur tangan pihak luar dan bebas dari segala tekanan baik fisik maupun psikis. Hal tersebut merupakan upaya agar tidak terjadi perbuatan, tingkah laku sikap dan/atau ucapan yang dapat merendahkan dan merongrong kewibawaan, martabat dan kehormatan badan peradilan yang dikenal sebagai "contempt of court" dan telah diamanahkan juga oleh pertimbangan hukum huruf c dari UU No. 48 Tahun 2009 tentang Kekuasaan Kehakiman.

\section{Kebijakan Hukum Pidana UU No. 48 Tahun 2009 Tentang Kekuasaan Kehakiman Ke Depan}

Istilah kebijakan hukum pidana lazim juga disebut dengan pembaruan hukum pidana. Kebijakan berasal dari istilah Inggris policy yang berarti kebijakan. Istilah policy sering juga disebut politik sehingga kebijakan hukum pidana disebut juga dengan politik hukum pidana atau kebijakan formulatif yang diartikan sebagai "upaya untuk melakukan reorientasi dan reformasi hukum pidana yang sesuai dengan nilai-nilai sosio politik, sosio filosofis, serta sosiokultural masyarakat Indonesia yang melandasi kebijakan sosial, kebijakan kriminal dan kebijakan penegakan hukum di Indonesia". ${ }^{19}$

Campur tangan hukum pidana amat diperlukan, pada dasarnya berguna untuk menengok jalannya persidangan, dimana penegak hukum hakim sebagai pejabat negara dapat dipidana. Pengaturan yang kaku, dan bertolak belakang, dengan penegakan hukum, yaitu ketika Surat Edaran Mahkamah Agung, mempunyai kedudukannya sejajar dengan Undang-undang. Surat Edaran Mahkamah Agung (SEMA) No. 9 Tahun 1976 yang pada pokoknya menyebutkan bahwa hakim dalam mengambil keputusan tidak dapat diganggu gugat. "Keberadaan SEMA tersebut menjadi tameng putusan-putusan hakim yang cacat substansi dan cacat prosedur (yang mengandung unsur kejahatan dalam jabatan)". ${ }^{20}$

\footnotetext{
${ }^{18}$ Lihat Undang-undang No. 14 Tahun 1985 tentang Mahkamah Agung (Lembaran Negara Republik Indonesia Tahun 1985 Nomor 73, Tambahan Lembaran Negara Republik Indonesia Tahun 1985 Nomor 3316).

${ }^{19}$ Barda Nawawi Arief, Kebijakan Hukum Pidana, Perkembangan Penyusunan Konsep KUHP Baru, Jakarta: Kencana Prenada Media Group, (2008.)

${ }^{20}$ O.C. Kaligis, Kejahatan Jabatan dalam Sistem Peradilan Terpadu, Bandung: PT Alumni, (2011).
} 
Hakim dilarang menolak perkara yang itu tidak ada dasar hukumnya, ataupun keputusan hakim dianggap benar, kecuali dapat dibuktikan sebelumnya. Pemikiran berupa asas-asas tersebut yang memperkokoh kedudukan hakim dalam persidangan. Oleh sebab itu kebijakan penegakan hukum sebagaimana ditentukan Pasal 3 ayat (3) Undangundang No. 48 Tahun 2009 tentang Kekuasaan Kehakiman perlu ditegakkan, yang menyebutkan "Setiap orang yang dengan sengaja melanggar ketentuan sebagaimana dimaksud pada ayat (2) dipidana sesuai dengan ketentuan peraturan perundangundangan". ${ }^{21}$ Hakim pun dapat melakukan penghinaan pengadilan.

Hukum pidana yang merupakan bagian dari suatu kebijakan, diperlukan satu kesatuan sistem hukum mengatur tentang perbuatan, pertanggungjawaban, penitensier, hukum prosedur, yang berarti antara perbuatan pidana, harus selaras dengan pertanggungjawaban pidananya, dan seimbang dengan bagaimana penjatuhan pidananya. begitu pula apabila mencermati norma suatu pasal, yang artinya pada persoalan ini antar ayat-ayat dalam satu pasal saling berhubungan sebagai norma yang berpasangan, dan diperlukan kejelasan dari masing-masing ayat, yang sementara ini satu kesatuan sistem hukum membutuhkan kejelasan tadi dalam satu undang-undang belum tersusun dengan baik dimana ketentuan pidananya menunjuk pada perundang-undangan lain dan masih terpencar (spread out).

Mencermati norma hukum, pemikiran-pemikiran di atas, norma hukum Pasal 3 ayat (3), sebagai norma yang dilandasis sebuah kebijakan, yaitu kebijakan kriminal yang dilandasi oleh kondisi sosio pada saat ini, maka dikatakan lebih luas lagi sebagai kebijakan hukum pidana, yang berarti bahwa usaha kebijakan hukum pidana tidak dapat dilepaskan dari politik kriminal, yang pengertiannya identik dengan kebijakan penanggulangan kejahatan dengan hukum pidana sebagai sarana utama. Menurut M. Ali Zaidan, ${ }^{22}$ "Peraturan perundang-undangan yang baik (dalam perumusan, sistem sanksi serta harmonisasi vertikal dan horizontal) merupakan prasyarat yang menentukan langkah penegakan hukum selanjutnya yakni bekerjanya sistem peradilan pidana."

Konsekuensi yuridisnya, kebebasan karena kekuasaan kehakiman yang secara normatif ditentukan dalam perundang-undangan melalui asas kemandirian peradilan perlu dibatasi dengan suatu kebijakan hukum pidana untuk bekerjanya Sistem Peradilan Pidana, tentunya hal ini berlandaskan Teori Keadilan dari Herbert L Packer yaitu :

Crime control model, penggunaan kekuasaan terhadap setiap kejahatan dan pelaku kejahatan, hal ini disebabkan model ini memilki asumsi bahwa setiap orang yang terlibat (tersangka) dalam criminal justice system ada kemungkinan bersalah, dan due process model dimana sebagai dasar nilai pada asas praduga tak bersalah (presumption of innocence), yang mempunyai tujuan utama melindungi seseorang yang sungguh-sungguh tidak bersalah dan menuntut mereka yang benar-benar bersalah. ${ }^{23}$

\footnotetext{
${ }^{21}$ Loc.cit. Undang-undang No. 48 Tahun 2009 tentang Kekuasaan Kehakiman.

${ }^{22}$ M.Ali Zaidan, Kebijakan Kriminal. Jakarta: Sinar Grafika, (2016).

${ }^{23}$ Herbert L. Packer, The Limits of The Criminal Sanction, California: Standford University Press, (1968).
} 
Menurut Barda Nawawi Arief, "pembaruan hukum bukan merupakan suatu usaha yang bersifat vast leggen van wat is (menetapkan apa yang sudah berlaku), tetapi lebih merupakan suatu usaha vast leggen wat hoort te zijn (penetapan apa yang seharusnya atau sebaliknya berlaku)". ${ }^{24}$ Undang-undang merupakan bagian dari suatu kebijaksanaan tertentu, ia tidak hanya alat untuk melaksanakan kebijaksanaan, tetapi juga menentukan, menggariskan atau merancangkan suatu kebijaksanaan.

Pembentukan norma hukum pada umumnya harus mengandung tujuan-tujuan tertentu yang dianggap mulia. Hal ini disebabkan karena hukum merupakan sistem yang bertujuan. Politik hukum pidana tidak saja menyangkut kebijakan perundang-undangan, akan tetapi juga menyangkut kebijakan yang akan ditetapkan oleh hakim dalam menjatuhkan hukuman terutama berkaitan dengan perampasan kemerdekaan. Hakim diharapkan menggunakan "kebijakan/kearifan dalam menetapkan jenis sanksi yang akan dikenakan kepada terdakwa. Politik hukum pidana yang merupakan bagian dari kebijakan perundang-undangan disamping merupakan politik dalam rangka penanggulangan kejahatan yang menjadi ranah pengadilan untuk menentukan tindakan yang harus diambil guna menanggulangi kejahatan". ${ }^{25}$

Berdasar pemikiran di atas, norma Pasal 3 ayat (2) UU No. 48 Tahun 2009 tentang Kekuasaan Kehakiman yang tidak sesuai dengan kultur peradilan bahwa campur tangan urusan peradilan (fungsi peradilan) secara faktual kasuistis tidak disebabkan oleh pihak luar saja tetapi juga pihak dalam pengadilan, dengan akibat terjadinya contempt of court dengan pelaku hakim, hasil penelitian Nur Kholis, menegaskan bahwa:

"Kitab Undang-Undang Hukum Pidana tidak mengatur tentang tindak pidana contempt of court, akan tetapi hanya perbuatan atau tindak pidana dalam Kitab Undang-undang Hukum pidana dikategorikan masuk ke dalam ranah tindak pidana contempt of court, sehingga Hakim (pengadilan) hanya menjadi objek hukum dari tindak pidana contempt of court. Asas non diskriminasi dapat di terapkan terhadap tindak pidana contempt of court karena seluruh subjek hukum harus sama di depan hukum, sehingga dalam penerapan asas non diskriminasi hakim akan menjadi subjek hukum, jadi ada pergeseran konsep yang dari semula hakim menjadi objek hukum sekarang juga masuk sebagai subjek hukum karena didasari oleh asas non diskriminasi. Norma sebagai pengaturan contempt of court dinyatakan dengan "setiap orang". ${ }^{26}$

Selanjunya beliau mengemukakan bahwa "Hakim juga harus dimasukkan ke dalam tindak pidana contempt of court sebagai subjek hukum, karena berdasarkan asas non diskriminasi semua subjek hukum harus diperlakukan sama di depan hukum, apabila subjek hukum itu melanggar hukum dalam tindak pidana contempt of court. "27 Posisi hakim karena asas non diskriminasi, sebagai subjek hukum yang sama dengan pencari keadilan, memegang peranan untuk melakukan suatu tindak pidana. Menurut Mudzakir,

24 Barda Nawawi Arief, Kebijakan Legislatif Dalam Penanggulangan Kejahatan dengan Pidana Penjara, Yogyakarta: Genta Publishing, (2010).

${ }^{25}$ M.Ali Zaidan, Menuju Pembaruan Hukum Pidana, Jakarta: Sinar Grafika, (2015).

${ }^{26}$ Nur Kholis, "Asas Non Diskriminasi Dalam Contempt Of Court”, Jurnal Legality 26 no. 2 (2018).

${ }^{27}$ Ibid 
sebaiknya perlu dipikirkan bahwa "Tindak Pidana contempt of court dapat dilakukan oleh siapa saja". ${ }^{28}$

Lemahnya posisi hakim terhadap terjadinya tindakan pelecehan ini, bahwa kemandirian hakim terkooptasi pada atasan secara langsung yaitu Mahkamah Agung, yang seharusnya melakukan pengawasan internal saja, akan tetapi sebaliknya dapat melakukan pemanggilan pada hakim majelis, dan sekaligus dapat melakukan tindakan mutasi pada hakim-hakim dalam jajarannya, disamping itu pengawasan hakim dilakukan oleh Komisi Yudisial. "Komisi Yudisial resmi menerima laporan dari Koalisi Masyarakat Anti Korupsi terkait 2 (dua) hakim Mahkamah Agung yang memutus lepas mantan Ketua Badan Penyehatan Perbankan Nasional Syafruddin Arsyad Temenggung atau disingkat SAT dalam kasus dugaan korupsi Surat Keterangan Lunas Bantuan Likuiditas Bank Indonesia (SKL BLBI)". ${ }^{29}$

Hakim dalam memutuskan sebuah perkara tidak terlepas dari teori-teori pemidanaan yang ada dalam pertimbangan-pertimbangan putusan, teori pemidanaan yang digunakan hakim diharapkan agar dalam pertimbangannya hakim memutus perkara atau menjatuhkan hukuman seadil-adilnya sesuai dengan berat ringannya tindak pidana dan akibat yang ditimbulkan oleh sipelaku tindak pidana. Agar penjatuhan pidana yang diberikan kepada pelaku tindak pidana memberikan efek jera, manfaat bagi diri pelaku dan bagi masyarakat umum. ${ }^{30}$

Hukum pidana merupakan hukum yang bersangksi pidana maka larangan tersebut adalah representatatif agar peraturan tersebut memilki kekuatan memaksa dan norma hukum tersebut memperoleh pengakuan dari elemen bangsa di Indonesia untuk ditegakkan dengan substansi ketentuannya bersifat umum apabila berkaitan dengan KUHP, dan memenuhi asas-asas lain yang berkaitan dengan terjadinya konflik norma. Oleh karena itu, memperhatikan implikasi berdasarkan regulasi pembentukan perundang-undangan yang mempersoalkan tindak pidana terhadap peradilan sarat terhadap usulan serta dalam kondisi pro dan kontra terhadap perlu diatur dalam RKUHP ataukah RUU CoC, maka sesuai dengan perbuatan, subjek pelaku dan objek yang diatur menyangkut campur tangan, maka permasalahan berkaitan dengan ruang lingkupnya yaitu kekuasaan kehakiman, menurut hemat penulis perlu perubahan kebijakan UU No. 48 Tahun 2009 tentang Kekuasaan Kehakiman.

Menurut Benny Riyanto, "penataan regulasi sangat diperlukan untuk memfilter agar penyakit regulasi dapat ditangani, dan hal tersebut telah diatur dalam undang-undang terbaru mengenai pembentukan peraturan perundang-undangan". ${ }^{31}$ Pasal 95 A dan 95 B

${ }^{28}$ Mudzakir, Tindak Pidana Terhadap Proses Peradilan, Seminar Nasional Advokat dan Contempt of Court dalam RKUHP, 26 Nopember 2019, Malang: Kerjasama Peradi Pusat dengan Universitas Muhammadiyah Malang, (2019).

${ }^{29}$ https://www.cnnindonesia.com/nasional/201907231611857-12-414790/ky-usut-dua-hakim-ma-yang bebaskan-syafruddin-temenggung, KY usut dua hakim MA yang bebaskan syafruddin Temanggung, diakses 30 Juli 2019, pukul 13.20 WIB.

${ }^{30}$ Bella Verawaty Arnas, Remon Supusepa, Margie Gladies Sopacua, "Pertimbangan Hukum Hakim Dalam Putusan Pengadilan Negeri Ambon Nomor 306/Pid.B/2020/PN.Ambon Terhadap Perampasan Jenazah Covid-19 Dalam Prespektif Tujuan Pemidanaan” Jurnal Ilmu Hukum Tatohi 1, no. 7 (2021): 654-671.

${ }^{31}$ Benny Riyanto, Penataan Regulasi di Indonesia, Disampaikan pada Seminar Nasional dan Kolokium Ke II, (Malang: Program Studi Doktor Ilmu Hukum FH UB, 2021) 
Undang-undang No. 15 Tahun 2019 tentang Perubahan Atas Undang-undang Nomor 12 Tahun 2011 Tentang Pembentukan Peraturan Perundang-undangan ${ }^{32}$ bahwa:

"Pasal 95A menyebutkan (1) Pemantauan dan Peninjauan terhadap undangundang dilakukan setelah undang-undang berlaku. (2) Pemantauan dan Peninjauan terhadap undang-undang sebagaimana dimaksud pada ayat (1) dilaksanakan oleh DPR, DPD, dan Pemerintah. (3) Pemantauan dan Peninjauan terhadap undang-undang sebagaimana dimaksud pada ayat (1) dikoordinasikan oleh DPR melalui alat kelengkapan yang khusus menangani bidang legislasi. (4) Hasil dari Pemantauan dan Peninjauan terhadap undang-undang sebagaimana dimaksud pada ayat (21 dapat menjadi usul dalam penyusunan Prolegnas. Pasal 95B menyebutkan (1) Pemantauan dan Peninjauan terhadap undang-undang dilaksanakan dalam 3 (tiga) tahap sebagai berikut: a. tahap perencanaan; b. tahap pelaksanaan; dan c. tahap tindak lanjut. (2) Ketentuan lebih lanjut mengenai Pemantauan dan Peninjauan terhadap Undang-Undang diatur masing-masing dengan Peraturan DPR, Peraturan DPD, dan Peraturan Presiden".

Pemantauan dan peninjauan menurut Pasal 1 ayat 14 undang-undang di atas bahwa "Pemantauan dan Peninjauan adalah kegiatan untuk mengamati, mencatat, dan menilai atas pelaksanaan undang-undang yang berlaku sehingga diketahui ketercapaian hasil yang direncanakan, dampak yang ditimbulkan, dan kemanfaatannya bagi Negara Kesatuan Republik Indonesia”. ${ }^{33}$

\section{E. PENUTUP}

Campur tangan urusan peradilan dalam Pasal 3 ayat (2) UU No. 48 Tahun 2009 tentang Kekuasaan Kehakiman dengan contempt of court memilki hubungan dengan alasan kekuasaan kehakiman yang merdeka, peradilan yang bersih, serta berwibawa merupakan pertimbangan hukum UU No. 48 Tahun 2009 tentang Kekuasaan Kehakiman yang dapat dikaitkan dengan perbuatan yang merendahkan kewibawaan badan peradilan atau contempt of court. Jadi kedua perbuatan tersebut pada hakekatnya melindungi kewibawaan pelaku kekuasaan kehakiman, dan para pihak dalam perselisihan pada badan peradilan. Dalam bentuknya sebagai suatu kebijakan hukum pidana maka dapat memberikan kekuatan memaksa Pasal 3 ayat (2) Undang-undang No. 48 Tahun 2009 tentang Kekuasaan Kehakiman, melalui pengusulan perubahan UU tersebut sebagai hukum pidana khusus ke depan.

\section{DAFTAR PUSTAKA}

Ali Zaidan, M, Menuju Pembaruan Hukum Pidana, (Jakarta: Sinar Grafika, 2015).

Edi Subiyanto, Achmad, "Mendesain Kewenangan Kekuasaan Kehakiman Setelah Perubahan Uud 1945", Jurnal Konstitusi 9 no. 4 (2012) http://dx.doi.org/10.31078/jk\%x

\footnotetext{
${ }^{32}$ Undang-undang No. 15 Tahun 2019 entang Perubahan Atas Undang-undang Nomor 12 Tahun 2011 Tentang Pembentukan Peraturan Perundang-undangan (Lembaran Negara Republik Indonesia Tahun 2019 Nomor 183, Tambahan Lembaran Negara Republik Indonesia Nomor 6398)

${ }^{33}$ Ibid
} 
Fitriciada Azhari, Aidil, Paradigma Kekuasaan Kehakiman Sebelum dan Sesudah Reformasi dalam Meluruskan Arah Manajemen Kekuasaan Kehakiman, Jakarta: Sekretaris Jenderal Komisi Yudisial Republik Indonesia, (2018)

Floranta Adonara, Firman, "Prinsip Kebebasan Hakim dalam Memutus Perkara Sebagai Amanat Konstitusi”, Jurnal Konstitusi 12 no. 2 (2015) http://dx.doi.org/10.31078/jk1222

Hidayat, Arif and Zaenal Arifin, "Politik Hukum Legislasi Sebagai Socio-Equilibrium Di Indonesia", Jurnal Ius Constituendum 4 no. 2 (2019) http://dx.doi.org/10.26623/jic.v4i2.1654

https://www.kamusbesar.com/campur-tangan, turut mencampuri (memasuki) perkara orang lain; (arti; tersangkut atau terlibat dl suatu tindakan kejahatan (perkara orang lain dsb); (arti), diakses 5 Oktober 2021, pukul 12.06 WIB

https://www.cnnindonesia.com/nasional/201907231611857-12-414790/ky-usut-duahakim-ma-yang-bebaskan-syafruddin-temenggung, KY usut dua hakim MA yang bebaskan syafruddin Temanggung, diakses 30 Juli 2019, pukul

Kaligis, O.C., Kejahatan Jabatan dalam Sistem Peradilan Terpadu, Bandung: PT Alumni, (2011) Kerjasama Peradi Pusat dengan Universitas Muhammadiyah Malang, 2019.

Kholis, Nur, "Asas Non Diskriminasi Dalam Contempt Of Court”, Jurnal Legality 26, no. 2 (2019): 235.

Mudzakir, Tindak Pidana Terhadap Proses Peradilan, Seminar Nasional Advokat dan Contempt of Court dalam RKUHP, 26 Nopember 2019, Malang.

Nawawi Arief, Barda, Kebijakan Hukum Pidana, Perkembangan Penyusunan Konsep KUHP Baru, Jakarta: Kencana Prenada Media Group, (2008)

, Kebijakan Legislatif Dalam Penanggulangan Kejahatan dengan Pidana Penjara, Yogyakarta: Genta Publishing, (2010)

Nurhidayat, Syarif, "Pengaturan Dan Ruang Lingkup Contempt Of Court Di Indonesia", Jurnal Ius Constituendum 6 no. 1 (2021) http://dx.doi.org/10.26623/jic.v6i1.2419

Purnama Puteri, Rizqi, and Muhammad Junaidi, Zaenal Arifin, "Reorientasi Sanksi Pidana Dalam Pertanggungjawaban Korporasi Di Indonesia”, Jurnal USM Law Review 3, no. 1 (2020): 98-111, http://dx.doi.org/10.26623/julr.v3i1.2283

Ridha Hakim, Muh, "Tafsir Independensi Kekuasaan Kehakiman Dalam Putusan Mahkamah Konstitusi”, Jurnal Hukum dan Peradilan 7, no. 2 (2018): 279 - 296, http://doi.org/10.25216/jhp.7.2.2018.279-296

Riyanto, Benny, Penataan Regulasi di Indonesia, Disampaikan pada Seminar Nasional dan Kolokium Ke II, (Malang: Program Studi Doktor Ilmu Hukum FH UB, 2021)

Sanjaya, Aditya Wiguna, "Celah Intervensi Kekuasaan Eksekutif Terhadap Kekuasaan Yudikatif Di Lingkungan Peradilan Militer", Jurnal Panorama Hukum 3, no. 2 (2018): 206, https://doi.org/10.21067/jph.v3i2.2823

Subarkah, Ibnu and Lukman Hakim, "Penanggulangan Campur Tangan Urusan Peradilan Di Luar Kekuasaan Kehakiman Berbasis Penal Reform". Yustisia 4 no. 2 (2015) https://doi.org/10.20961/yustisia.v4i2.8650

Undang-undang No. 15 Tahun 2019 entang Perubahan Atas Undang-undang Nomor 12 Tahun 2011 Tentang Pembentukan Peraturan Perundang-undangan. 